\title{
The Effect of Transformational Leadership and Leader- Member Exchange on Knowledge Sharing Process: A Practice from Turkey
}

\author{
Dönüşümcü Liderlik ve Lider-Üye Değişiminin Bilgi Paylaşım Sürecine \\ Etkisi: Türkiye'den Bir Uygulama
}

\begin{abstract}
The objective of this study is to find out the effect of transformational leadership, accepted as an effective form of leadership, and leader-member exchange on knowledge sharing behaviors of the employees. Besides, it is aimed to determine empirically the mediating role of leader-member exchange in the relation between transformational leadership and knowledge sharing. Moreover, comparison of the results belonging to the blue and white-collar employees has been made in order to contribute to the literature. Data have been collected from 340 employees of a textile factory providing service in Istanbul and Bursa. According to the results of the research, it has been concluded in general terms that transformational leadership and leadermember exchange affect knowledge sharing process of employees in a positive manner, and the leader-member exchange plays a partial mediating role in the relation between transformational leadership and knowledge sharing. Unlike the results of the general model, in the analyses made with relation to blue-collar employees, it has been concluded that leader-member exchange has no effect on knowledge sharing, and also leader-member exchange has no mediating role. Furthermore, results of the analyses related to white-collar employees indicate similarity to the general model and it has been concluded that leader-member exchange has a full mediating role.
\end{abstract}

Öz

Bu çalışmanın amacı, etkili bir liderlik tarzı olarak kabul edilen dönüşümcü liderliğin ve lider-üye değişiminin, çalışanların bilgi paylaşma davranışlarına olan etkisini ortaya koymaktır. Ayrıca, dönüşümcü liderlik ile bilgi paylaşımı davranışı arasındaki ilişkide lider-üye etkileşiminin aracı rolünü ampirik olarak belirlemek amaçlanmaktadır. Bu doğrultuda literatüre katkı sağlamak adına, mavi ve beyaz yaka çalışanlara ait sonuçların karşılaştırması da yapılmaktadır. İstanbul ve Bursa'da faaliyet gösteren bir tekstil firmasının 340 çalışanından veriler toplanmıştır. Araştırma sonucuna göre, genel olarak dönüşümcü liderliğin ve lider-üye etkileşiminin çalışanların bilgi paylaşımını olumlu yönde etkilediği, ayrıca lider-üye etkileşiminin dönüşümcü liderlik ile bilgi paylaşımı arasındaki ilişkide kısmi aracılık etkisinin olduğu sonucuna ulaşılmıştır. Bu sonuçlardan farklı olarak, mavi yaka çalışanlar için yapılan analizlerde lider-üye etkileşiminin çalışanların bilgi paylaşımına etkisinin olmadiğı ve lider-üye değişiminin aracılık etkisinin olmadı̆̆ı sonucuna ulaşılmıştır. Ayrıca, beyaz yaka çalışanlara ait analiz sonuçları genel modelle benzerlik göstermekle birlikte, lider-üye değişiminin tam aracılık etkisinin olduğu sonucuna ulaşılmıştır.

\section{Introduction}

Knowledge is considered as the most important source of a company and has a strategic place among all other sources. Day by day, success of business in all sectors becomes more and more dependent on knowledge and critical importance of the knowledge increasingly is understood. Knowledge provides sustainable competitive advantage for the companies and positively affects their capability of creating values and performance (Du et al., 2007: 38). In addition, knowledge plays a key role in comprehension of new techniques, problem-solving, development of basic competencies, and provision of sustainable innovation in individual terms (Liao et al., 2007: 341). 
Moreover, knowledge provides basic skills for achievement of individual and organizational targets (Phong et al., 2018: 706). In this context, successful management of knowledge is a highly critical process for the companies. The success of knowledge management depends on the efficacy of the knowledge sharing process which is one of the basic functions of knowledge management (Le \& Lei, 2017: 480).

An effective knowledge sharing process offers opportunities not only for successful knowledge management but also for mutual learning of employees, enables organizational learning, increases the organizational ability to the highest level, and contributes to enhancement of competitive advantage by the companies (Han et al., 2016: 131; Phong \& Son, 2020: 2). Besides, knowledge sharing has an important effect on providing the knowledge and skills needed to increase organizational capacity, improve organizational and individual productivity, and achieve organizational goals (Le \& Lei, 2017: 480).

The critical significance of knowledge sharing for organizations and guidance of employees for knowledge sharing have become important issues nowadays. During the process starting from notice of the importance of knowledge sharing, various systems and methods have been designed in order to facilitate knowledge sharing. However, it has been noticed that the biggest obstacle to the effective management and sharing of knowledge is the attitude of people rather than ineffective systems and methods (Hao et al., 2019: 2). Perception of knowledge as 'power' by the employees and the fear of losing superiority or personal privileges experienced after knowledge sharing can increase reluctance for knowledge sharing (Li et al., 2014: 554; Yang, 2008: 347). Changing attitudes and behaviors of employees towards knowledge sharing can only be possible by strong personal motivation (Ipe, 2003: 345). In this context, enabling employees to share knowledge with each other and motivating them to this end are significant administrative challenges. In this context, enabling employees to share knowledge with each other and motivating them to this end are significant administrative challenges. Besides, sharing knowledge with each other is considered as a compulsory behavior for the employees to fulfil their obligations, rather than an optional action.

Knowledge is an element stored or created in minds of individuals and required to be shared with the members of the organization in order to transform it into a value. Knowledge begins at individual level and expands up to group and organizational level. Knowledge should be shared to gain value. As sharing knowledge results in formation of new knowledge, enhancement of old knowledge and emergence of more knowledge in the future, it has a critical importance for the organization (Fong et al., 2011: 706-707). In this scope, factors affecting the success of knowledge sharing should be searched; leadership styles are the main factors in this regard, and they should be examined as the antecedents of knowledge sharing.

Knowledge sharing within the organization is not realized automatically. Knowledge sharing is realized only when required conditions are met. In this context, the role of the leader having a powerful effect on knowledge sharing process is of great importance (Srivastava et al., 2006: 2006). Leadership is a significant element either encouraging or preventing knowledge sharing among employees (Choi et al., 2016: 464). Leadership behaviors and styles shape general attitudes and behaviors of the employees and have significant effect on formation and support of employees' behaviors towards knowledge sharing (Le \& Lei, 2019: 531). On the other hand, a great obligation falls upon the leader to create an atmosphere (climate) enabling knowledge sharing among employees in order to contribute to the organization (Lin \& Lee, 2004: 108). The leader is of great importance for increasing motivation of the employees and activating their positive attitudes and behaviors towards the organization (Han et al., 2016: 134). Therefore, the number of researches trying to prove that the leader is the antecedent of the knowledge sharing of employees is increasing day by day. There are studies in the literature about positive effects of ethical leadership (Bavik et al., 2017), empowering leadership (Srivastava et al., 2006), transactional leadership (Bryant, 2003), and leader-member exchange (Sharifkhani et al., 2016) on knowledge sharing.

The leader is of great importance for increasing motivation of the employees and activating their positive attitudes and behaviors towards the organization (Han et al., 2016: 134). Therefore, the number of researches trying to prove that the leader is the antecedent of the knowledge sharing of 
employees is increasing day by day. There are studies in the literature about positive effects of ethical leadership (Bavik et al., 2017), empowering leadership (Srivastava et al., 2006), transactional leadership (Bryant, 2003), and leader-member exchange (Sharifkhani et al., 2016) on knowledge sharing. The leader, having a significant influence on attitudes and behaviors of the employees, also plays an important role in success or failure of the organization. As distinct from other leadership forms, transformational leadership considers the employees as a valuable source and gives them inspiration to increase organizational performance in order to achieve organizational success (Phong et al., 2018: 706). In other words, Bass (1985) states that the transformational leader creates an inspiring mission, objective and sense of identity emphasizing significance and value of organizational targets, and motivates the employees to display performance beyond expectations. It is stipulated that transformational leadership form is one of the most appropriate forms of leadership encouraging employees to participate in knowledge sharing process (Le \& Lei, 2019: 528). Furthermore, it has been put forward by studies that leader-member exchange, which is another form of leadership depending upon exchange and reciprocity theories, has serious effects on knowledge sharing process (Hao et al., 2019: 2). Graen (1995) asserts that a high quality leadermember exchange can motivate the employees to internalize the targets of the organization and the leader. Such internalization may encourage creation of trust between the leader and the employee, and accordingly realization of knowledge sharing (Carmeli et al., 2011: 258).

While transformational leadership is adopted as an effective form of leadership for successful knowledge sharing process, it is thought that the relation between transformational leadership and knowledge sharing and the mediating roles of other factors defining such relation need to be searched further. The objective of this study is to put forward the effects of transformational leadership, accepted as an effective form of leadership, and leader-member exchange on knowledge sharing behaviors of the employees. Moreover, it is aimed to determine empirically the mediating role of leader-member exchange in the relation between transformational leadership and knowledge sharing. Both interaction processes of blue and white-collar employees with the leader and their organizational outputs may be different from each other. In this context, comparison of the results belonging to the blue and white-collar employees has been made in order to contribute to the literature.

\section{Literature Review}

\subsection{Transformational Leadership}

Transformational leadership has been put forward as a political form of leadership for the first time by Burns (1978). Idea of transformational leadership has been introduced as an organizational management approach for the first time by Bass (1985) (Kuhnert \& Lewis, 1987: 648). Bass (1985) defines transformational leadership in terms of the employees as desisting from personal benefits for the interest of the organization and being motivated for performance higher than the expected. In another definition, transformational leadership is explained as a process of forming loyalty towards the mission, targets and strategies of the organization by changing the attitudes and priorities of the employees (Yukl, 1989: 269).

Transformational leaders exhibit a huge collective aim, mission or vision for the organization and inspire the employees to go beyond their own benefits (Howell \& Avolio, 1993: 891). According to Bass \& Avolio (1994), transformational leadership, focusing on the relation between the leaders and their followers, comprehends the needs of the employees and motivate them to reach full potential. Thought as a motivational type of leadership, transformational leadership becomes a source of inspiration for the employees by the vision it offers, and contributes to positive organizational outputs (Fitzgerald \& Schutte, 2010: 495).

Transformational leader focuses on change and development of the organization; to this end, he/ she firstly shows effort to change the needs, beliefs and values of the employees (Macit, 2003: 9697). In this line, there are certain behaviors adopted typically by the transformational leader. Such behaviors also differentiate the transformational leader from other forms of leadership. Some of them are as follows: the transformational leader inspires his/her followers, as a leader with 
inspiration abilities, to achieve the highest level of success and outputs; encourages and supports the employees to reach and even go beyond the organizational targets; persuades the employees to put organizational interests before personal benefits; encourages the employees to develop their skills and gain new ones; and constantly seeks for new opportunities to improve the organization (Le and Lei, 2017: 484; Phong and Son, 2020: 4).

Bass \& Avolio (1997) have examined the behaviors of transformational leadership under four titles; idealized influence, inspirational motivation, intellectual stimulation, and individualized consideration. Idealized influence characterizes behaving of a leader within ethics and principles; it reflects his/her aspect reviving respect and trust in followers and inspiring them for ethical behaviors. Inspirational motivation indicates the ability of a leader to motivate the employees by means of a strong sense of aspiration and vision. Intellectual stimulation reflects the aspect of a leader to encourage his/her employees for gaining the skills required to solve problems. Individualized consideration reflects the aspect of a leader to increase motivation and satisfaction of the employees by showing particular attention to their needs.

\subsection{Knowledge Sharing}

"Knowledge", accepted as a cognitive phenomenon in the minds of individuals, is defined by Davenport and Prusak (1998) as "component of experiences, values, contextual knowledge and expert opinions" in terms of organization. Nonaka (1994) has divided knowledge into two categories: explicit and implicit. Explicit knowledge is a knowledge type, which does not belong to a specific person but can be recorded, reached and comprehended. On the other hand, implicit knowledge contains the cognitive and technical components owned by the individual; it is a type of knowledge which is difficult to be adopted by the organization.

Expressed as a synergic cooperation among employees towards a common goal, knowledge sharing has been defined by H.-F. Lin (2007) as "a social interaction culture including mutual exchange of knowledge, experiences and skills of employees within the organization". According to Bartol \& Strivastava (2002), knowledge sharing refers to sharing of knowledge, opinions, suggestions and experiences among employees within the organization. It is aimed by means of knowledge sharing at individual level to make individuals give permission for the use of their knowledge at organizational level. It is aimed at organizational level to transform the obtained new knowledge into an economic and competitive value (Mohammadi \& Boroumand, 2016: 87). Moreover; knowledge sharing, which is defined as an action of knowledge transfer or distribution between individuals or groups, has the potential of increasing innovation capacity of the organization to a higher level (Carmeli et al., 2011: 258).

Knowledge sharing process is composed of two different behaviors as knowledge donation and knowledge collection. Knowledge donation reflects the degree of volunteering and proactiveness for transferring the personal knowledge to the colleagues. Knowledge collection is stated as consulting to colleagues in order to gain skills and knowledge (H.-F. Lin, 2007: 318). Success of knowledge sharing process depends upon the attitudes, perspectives and motivation of employees towards knowledge sharing (Gagne, 2009: 572).

\subsection{Leader-Member Exchange}

Developed as an alternative for average leadership forms, leader-member exchange has been called as "Vertical Dyad Linkage" for the first time by Dansereau et al. (1975). Studies made afterwards, Graen et al. (1982) have called this concept as leader-member exchange. Leader-member exchange theory depends upon the relation formed between the leaders and the employees. The relation between the leader and the employees differ from one person to another; leader-member exchange explains what kind of a key role the leader's effect play in such mutual relation (Dansereau et al., 1975: 49). According to leader-member exchange theory, the leader forms different relations with each of his subordinates and accordingly the exchange is realized with different qualities (Sherony \& Green, 2002: 542). Graen \& Uhl-Bien (1995) emphasizes that the leader has no aim to discriminate by developing different relations with his/her subordinates in leader-member exchange; on the contrary, he/she aims to understand the mode of cooperation with each subordinate and to develop a partnership. 
Graen \& Uhl-Bien (1995) explains leader-member exchange according to the role theory. According to such theory, the employees establish relation with the leader in three steps: role taking, role making, and role routinization. The employees firstly take a role within the organization, and then the quality of the relation between the employees and the leader is shaped as per the fulfilment of the taken role and performance. If the employees meet the expectations by their performances, a permanent and high quality relation is developed. The leader evaluates the employees according to their roles and degree of satisfying the expectations, and he/she develops both material and behavioral responses (Dansereau et al., 1975: 51).

Wayne et al. (1997) have handled leader-member exchange within the framework of social exchange theory. They have addressed the relation of leader with his/her employees within the framework of an economic exchange under a contract or a social exchange out of contract. According to leader-member exchange, the amount of material element or knowledge exchanged between parties can vary as per the individual. The bigger the perceived value of tangible and intangible elements exchanged mutually is, the higher the quality of leader-member exchange is (Wayne et al., 1997: 87). Behavioral, social or material support of leaders affects their efforts and wills, and determines the level of contribution to be made by them. It is assumed that the employees act with the feeling of indebtedness and display extra role behaviors for the organization because of positive approaches of the leaders (Düger, 2020b: 1219).

\section{Relationship between Variables and Hypotheses}

\subsection{Transformational Leadership and Leader-Member Exchange}

Transformational leaders pay attention to the personal expectations and needs of the employees, and they strengthen their motivation by displaying individualized evaluation behavior. Hence, a high quality relationship is established between the leader and the employees within the framework of respect, loyalty and obligation (Carmeli et al., 2011: 260). Burns (1978) considers transformational leadership as a relation in which the leader increases the motivation of his/her employees to a higher level. Such statement indicates that transformational leadership may harmonize organizational and individual targets and result in high quality leader-member harmonization (Krishnan, 2005: 14). Deluga (1992) states that a transformational leader influences the social exchange with his/her employees at a significant degree. In other words, he asserts that transformational leadership sources from the mutual individualized relation between a certain employee and the leader. Such situation enables the transformational leaders to develop high-quality relations with the employees and to form a sense of common fate (Deluga, 1992: 245).

A transformational leader considers the employees as individuals and he/she gives them opportunities and acts as a coach to improve their abilities. Such situation leads to emergence of a significant exchange between the leader and the employees. Consideration of needs and wills of each individual separately enables creation of a friendlier atmosphere in the workplace. A leader, assigning significant works to the employees and making the work meaningful, can increase the quality of exchange between him/her and the employee (Lee, 2005: 657).

Graen \& Uhl-Bien (1995) have mentioned that leader-member exchange carries the characteristics of both transactional and transformational leaderships. They have asserted that the leader-member exchange starts as a transactional social exchange process and then turns into a transformational social exchange process. Lee (2005) has stated that the transformational leadership is a significant determinant of all aspects of leader-member exchange. In other words, it indicates that the transformational leadership has a greater influence on the quality of leader-member exchange than other forms of leadership. Thus, the following hypotheses are proposed:

$\mathrm{H}_{1}$ : Transformational leadership is positively related to leader-member exchange.

$\mathrm{H}_{1 \mathrm{a}}$ : Transformational leadership is positively related to leader-member exchange for the bluecollar workers.

$\mathrm{H}_{1 \mathrm{~b}}$ : Transformational leadership is positively related to leader-member exchange for the whitecollar workers. 


\subsection{Leader-Member Exchange and Knowledge Sharing}

Leader-member exchange is generally handled from two perspectives; low quality relation and high quality relation. In a low quality relation between the leader and the member, mutual expectations and acquisitions are low. In such an exchange, the employees are expected to fulfil only formal job descriptions. Moreover, the employees do not establish an emotional relation with the leader and such situation results in less motivation of the employees for organizational citizenship and knowledge sharing behavior (Su et al., 2013: 1073). In a high quality relation, mutual trust, respect and obligations come into prominence. In such an exchange, the employees tend to go beyond the expectations and voluntarily exhibit extra role behavior (Graen \& Uhl-Bien, 1995: 227). Therefore, it is required to handle the effect of leader-member exchange on knowledge sharing process of employees within the framework of high quality relation.

In a high quality leader-member exchange process, commitment of the employees to the work, their loyalty to the leader and tendency to work collectively are high and such situation leads to knowledge sharing among the individuals at high levels (Li et al., 2014: 558). In other words, high quality leader-member exchange may encourage the employees to experience positive job experiences, to exhibit extra role behaviors beyond the expectations, in other words to display voluntary behaviors such as knowledge sharing (Hao et al., 2019: 3). Graen \& Uhl-Bien (1995) have stated that realization of a high quality relation between the leader and the member can act as a motivator for the employees to internalize the targets of the organization and the leader. In the case that the employees are sure that the leader treats fairly and looks after their benefits, it is highly possible that they can help the leader achieve his/her targets (Carmeli et al., 2011: 259). Chowdury (2005) has mentioned that if the employees internalize targets of the organization and the leader, more sense of security occurs and knowledge sharing can be possible. It is thought accordingly that a high quality leader-member exchange can help stimulate knowledge sharing.

According to the social exchange theory and principle of reciprocity underlying the leadermember exchange theory, when the employees realize that they can have a gain, they feel obliged to response even though the time and type of the gain are uncertain (Kim et al., 2017: 150). In studies handling knowledge sharing process within the framework of social exchange, it has been found that the leader and organizational characteristics are predictors of knowledge sharing. Furthermore, it has been stated that the benefit and costs perceived by the employees are critical factors for knowledge sharing within the framework of social exchange theory (Wang and Noe, 2010: 115-116). Foundation of knowledge sharing is composed of knowledge transfer and knowledge acquisition processes, and such processes constitute an integral part of the social interaction or exchange among the individuals. Thus, the following hypotheses are proposed:

$\mathrm{H}_{2}$ : Leader-member exchange is positively related to knowledge-sharing processes.

$\mathrm{H}_{2 \mathrm{a}}$ : Leader-member exchange is positively related to knowledge-sharing processes for the bluecollar workers.

$\mathrm{H}_{2 b}$ : Leader-member exchange is positively related to knowledge-sharing processes for the white-collar workers.

\subsection{Transformational Leadership and Knowledge Sharing}

Lin C.P. (2007) asserts that leadership support makes the employees to be eager for both knowledge donation and knowledge collection, and it is an important factor for increasing eagerness of the employees for knowledge sharing. Transformational leadership forms a culture within the organization towards knowledge sharing and supports knowledge sharing behaviors of the employees. Organizational culture focused on knowledge sharing significantly paves the way for realization of knowledge sharing among the employees (Le \& Lei, 2017: 483). Furthermore, Birasnav et al. (2011) have mentioned that the transformational leaders make great contribution to creation of a supportive knowledge culture shaping the behaviors of employees towards contributing to knowledge management system.

Transformational leaders encourage the employees for knowledge sharing, as a form of leadership that can motivate the employees, guide them, stimulate development of new skills among the followers and constantly seek for new opportunities for organizational improvement (Carmeli 
et al., 2011: 259; Phong et al., 2018: 707). Shamir et al. (1993) consider the charismatic leadership behavior, an important behavior displayed in transformational leadership, as a key behavior shaping the beliefs, emotions and behaviors of the employees according to the behaviors of the leaders. It is understood that transformational leadership is a form of leadership suitable for encouraging the effective knowledge sharing process thanks to such aspects. Thus, the following hypotheses are proposed:

$\mathrm{H}_{3}$ : Transformational leadership is positively related to knowledge-sharing processes.

$\mathrm{H}_{3 \mathrm{a}}$ : Transformational leadership is positively related to knowledge-sharing processes for the blue-collar workers.

$\mathrm{H}_{3 \mathrm{~b}}$ : Transformational leadership is positively related to knowledge-sharing processes for the white-collar workers.

\subsection{The Mediating Role of Leader-Member Exchange}

Contrary to other forms of leadership, the transformational leadership gives priority to social and psychological exchange rather than economic exchange (Düger, 2020a: 320). Such an aspect of transformational leadership demonstrates similarity to the characteristics of a high-quality leadermember exchange. Graen \& Uhl-Bien (1991) states that if leader-member exchange is realized at high level, mutual trust, respect, loyalty and understanding increase and as a result transformational leadership occurs.

Graen \& Uhl-Bien (1995) emphasizes that leader-member exchange level realizes at three stages. These stages are respectively as follows: stranger, acquaintance and partner. As proceeding from the first stage to the third, an exchange occurs from transactional exchange to transformational type of exchange. In "stranger" stage, which occurs between the leader and the employer, the leader offers the employees the role obligations towards the job and evaluates whether the employees fulfil such roles with success or not. When the employee fulfils the roles related to the job, he/ she is given more responsibilities and authority. Accordingly, the relation between the leader and the employee becomes more mature. In other words, it is transformed into a high quality relationship. Highquality leader-member exchange enables the employees to be included in more task-oriented and arbitrary extra role behaviors (Lee \& Wei, 2008: 245).

In the studies included in the literature, it has been proven that leader-member exchange has a mediating role in the effect of transformational leadership on organizational commitment (Lee, 2005), relational identification (Carmeli et al., 2011), task performance, organizational citizenship behaviors (Wang et al., 2005), job performance (Shusha, 2013), employees' effectiveness, extra effort, satisfaction (Lee \& Wei, 2008), innovative behaviors (Gürçay, 2015), leader and organizational identification $(\mathrm{Ng}, 2017)$. In this context, it should be taken into account that leader-member exchange is a significant factor increasing the leadership effect on positive attitudes and behaviors of the employees. It is suggested that the transformational leadership directly affects knowledge sharing, and has an indirect effect on knowledge sharing by means of leader-member exchange. In case of establishment of a high-quality relation between the leader, which is an important factor of knowledge sharing, and the employees, the employees are expected to exhibit more effort for knowledge sharing. In such a case, leader-member exchange is expected to act as a mediator for knowledge sharing. Thus, the following hypotheses are proposed:

$\mathrm{H}_{4}$ : Leader-member exchange mediates the relationship between transformational leadership and knowledge-sharing processes.

$\mathrm{H}_{4 a}$ : Leader-member exchange mediates the relationship between transformational leadership and knowledge-sharing processes for the blue-collar workers.

$\mathrm{H}_{4 \mathrm{~b}}$ : Leader-member exchange mediates the relationship between transformational leadership and knowledge-sharing processes for the white-collar workers. 


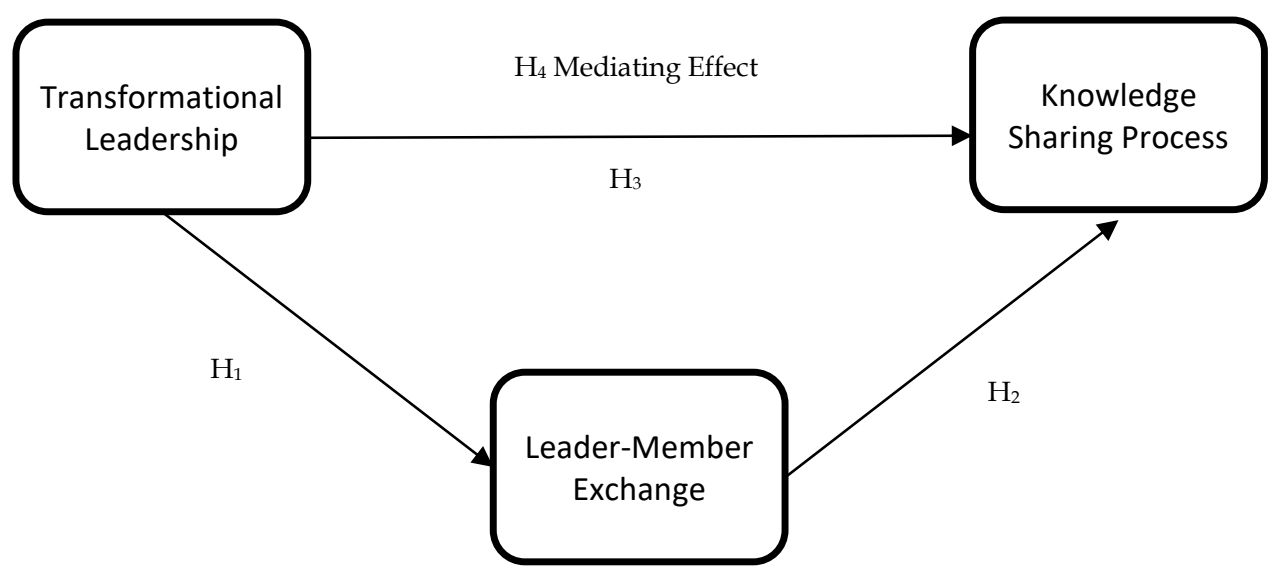

Figure 1. Research Model

\section{Research Methodology}

\subsection{Purpose, Scope and Method of the Research}

In this study, it is aimed to determine the effect of transformational leadership on knowledge sharing process and to put forward empirically the mediating role of leader-member exchange in this relation. Moreover, it is aimed to compare the relations between variables within blue and white-collar employees. In this context, a relational survey model was developed in the quantitative research method. The data required for the analysis have been obtained from the employees of the textile sector. As textile sector has a share of $7.2 \%$ in industrial export (Istanbul Textile and Apparel Exporters' Association, 2019) and provides employment for more than 1 million people in total when counted together with ready-to-wear sector (Cengiarslan, 2020), it is worth to investigate it. Within the scope of the research, blue and white collar employees of a textile company, operating in Istanbul and Bursa and having more than 6.000 employees including its subsidiaries, have been chosen as main group. In this scope, 500 questionnaire forms have been distributed to blue and white collar employees by hand and online by means of convenience sampling method in May-August 2020 period. 340 of such forms $(68 \%)$ have been considered as admissible (169 of them are blue collar and 171 of them are white collar). The questionnaire form is composed of two sections; the first section includes 6 statements towards determining demographic variables, and the second section includes 39 statements related to transformational leadership, knowledge sharing process and leadermember exchange scales.

\subsection{Data Collection and Analysis}

The data required for the research were obtained via the survey. Three scales are used in the research, consisting of transformational leadership, knowledge sharing process, and leader-member exchange. The transformational leadership scale; developed by Bass \& Avolio (1997) and it consists of four sub-dimensions (individualized consideration, intellectual stimulation, idealized influence, and inspirational motivation) and 20 statements. The knowledge-sharing process scale; developed by Lin H.-F. (2007) and it consists of two sub-dimensions (knowledge donating and knowledge collecting) and 7 statements. The leader-member exchange scale; developed by Liden \& Maslyn (1998) and it consists of four sub-dimensions (emotional impact, loyalty, contribution, and professional respect) and 12 statements. The statements used in the scales were measured using the 5 -point Likert-type rating scale $(1=$ Strongly Disagree $-5=$ Strongly Agree). Exploratory and 
confirmatory factor analysis was performed first with the data obtained through the questionnaire, and then correlation analysis was performed to reveal the relationship between variables. In line with the research model, path analysis and structural equation modeling were used to test the hypotheses. This study was ethically approved by the Social and Human Sciences Research and Publication Ethics Committee of Kütahya Dumlupınar University, with the decision of 2020/05, dated 21.05.2020.

\section{Research Findings}

\subsection{Demographic Findings}

Findings from 340 participants are presented separately as blue and white-collar workers. The demographic characteristics of 169 blue-collar workers participating in the; $17.80 \%$ are female, $82.20 \%$ are male, $45 \%$ of them are single and $55 \%$ are married. $12.40 \%$ of the employees are in the $18-25$ age group, $45 \%$ in the $26-30$ age group, $32 \%$ in the $31-39$ age group, $8.9 \%$ in the $40-54$ age group, and $1.8 \%$ in the 55 age and above. $43.2 \%$ of the participants are primary education, $49.7 \%$ high school, $5.3 \%$ associate degree, and $1.8 \%$ undergraduate. In addition, $39.60 \%$ of the participants have a working period of less than 1 year, 55\% 1-5 years, and 5.3\% 6-10 years. 55\% of the participants have 3.000 TL and less, 36.1\% 3.001 TL - 4.000 TL, and 8.9\% 4.001 TL - 5.000 TL income. Demographic findings of 171 white-collar workers; $36.3 \%$ are female, $63.7 \%$ are male, $42.1 \%$ of them are single and $57.9 \%$ are married. $18.8 \%$ of the employees are in the $18-25$ age group, $31.6 \%$ in the $26-30$ age group, $44.4 \%$ in the $31-39$ age group, $7.6 \%$ in the $40-54$ age group, and $0.6 \%$ in the 55 age and above. $1.8 \%$ of the participants are primary education, 31\% high school, $19.3 \%$ associate degree, $43.9 \%$ undergraduate and $4.1 \%$ graduate degree. In addition, $26.3 \%$ of the participants have a working period of less than 1 year, 56.1\% 1-5 years, 16.4\% 6-10 years, and 1.2\% 11-20 years. 17\% of the participants have $3.000 \mathrm{TL}$ and less, 50.90\% 3.001 TL - $4.000 \mathrm{TL}, 21.10 \% 4.001 \mathrm{TL}-5.000 \mathrm{TL}, 5.30 \%$ $5.001 \mathrm{TL}-6.000 \mathrm{TL}$, and 5.80\% 6.001 TL and above income.

\subsection{Reliability and Validity Analysis}

Principal component analysis as factor extraction method in order to determine the factor structures of the scales used in the research for the general model and blue and white-collar workers' models; varimax rotation is used as the rotation method. In addition, Bartlett's test was applied to test the suitability of the data set for factor analysis, and the Kaiser-Meyer-Olkin (KMO) value was calculated to test the sampling adequacy. In the exploratory factor analysis applied for the 39 scale items used in the study, the acceptance level for factor load values was determined to be at least 0.50 .

As a result of the analysis, KMO values for all models are between 0.724-0.924; Cronbach Alpha values are between $0.798-0.945$, and the total variance values explained were determined between 0.74-0.87. It was concluded that the results were sufficient for each factor and scale. According to Bartlett's Test statistics, the dual correlation coefficients between variables were found to be statistically significant $(\mathrm{p}<0.01)$. According to the results, it was concluded that the data were suitable for factor analysis. Factor loads of the expressions that create the factors, on the other hand, are between 0.579-0.943. All these results determined that the factor structures of all scales are uniformly distributed and reliable (Kalayc1, 2016: 405).

According to the results of the confirmatory factor analysis, expressions that were found to have factor loads below 0.70 were excluded from the analysis; 2 statements from the transformational leadership scale and 2 statements from the knowledge-sharing processes scale in the general model; 5 statements from the transformational leadership scale, 3 statements from the knowledge-sharing 
processes scale, and 1 statement on the leader-member exchange scale in the blue-collar workers model; 1 statement from the transformational leadership scale and 2 statements from the knowledge-sharing processes scale in the white-collar workers model. Exploratory factor analysis was made again after the statements extracted, detailed findings are given in Table 1.

Table 1. Exploratory Factor Analysis Findings

\begin{tabular}{|c|c|c|c|c|c|c|}
\hline \multicolumn{7}{|c|}{ General Model } \\
\hline Variables & $\begin{array}{c}\text { Sub- } \\
\text { Dimension }\end{array}$ & $\begin{array}{l}\text { Number } \\
\text { of Items }\end{array}$ & $\begin{array}{l}\text { Factor } \\
\text { Loading }\end{array}$ & $\begin{array}{c}\text { Total } \\
\text { Variance } \\
\text { Explained }\end{array}$ & $\begin{array}{c}\text { Cronbach's } \\
\text { Alpha } \\
\text { Value }\end{array}$ & $\begin{array}{c}\text { Kaiser- } \\
\text { Meyer- } \\
\text { Olkin }\end{array}$ \\
\hline \multirow{4}{*}{$\begin{array}{l}\text { Transformational } \\
\text { Leadership }\end{array}$} & II & 8 & $0.732-0.795$ & \multirow{4}{*}{$\% 74.39$} & \multirow{4}{*}{0.929} & \multirow{4}{*}{0.914} \\
\hline & IC & 3 & $0.699-0.743$ & & & \\
\hline & IM & 3 & $0.658-0.820$ & & & \\
\hline & IS & 4 & $0.799-0.845$ & & & \\
\hline \multirow{2}{*}{$\begin{array}{l}\text { Knowledge- } \\
\text { Sharing Processes }\end{array}$} & KD & 3 & $0.850-0.872$ & \multirow{2}{*}{$\% 79.03$} & \multirow{2}{*}{0.800} & \multirow{2}{*}{0.736} \\
\hline & KC & 2 & $0.865-0.892$ & & & \\
\hline \multirow{4}{*}{$\begin{array}{l}\text { Leader-Member } \\
\text { Exchange }\end{array}$} & PR & 3 & $0.776-0.843$ & \multirow{4}{*}{$\% 79.14$} & \multirow{4}{*}{0.905} & \multirow{4}{*}{0.876} \\
\hline & $\mathrm{CO}$ & 3 & $0.764-0.856$ & & & \\
\hline & LO & 3 & $0.733-0832$ & & & \\
\hline & AF & 3 & $0.835-0.886$ & & & \\
\hline \multicolumn{7}{|c|}{ Blue-Collar Workers } \\
\hline \multirow{4}{*}{$\begin{array}{l}\text { Transformational } \\
\text { Leadership }\end{array}$} & II & 6 & $0.693-0.811$ & \multirow{4}{*}{$\% 77.84$} & \multirow{4}{*}{0.896} & \multirow{4}{*}{0.848} \\
\hline & IC & 2 & $0.761-0.826$ & & & \\
\hline & IM & 3 & $0.633-0.841$ & & & \\
\hline & IS & 4 & $0.768-0.864$ & & & \\
\hline \multirow{2}{*}{$\begin{array}{l}\text { Knowledge- } \\
\text { Sharing Processes }\end{array}$} & KD & 3 & $0.850-0.943$ & \multirow{2}{*}{$\% 87.05$} & \multirow{2}{*}{0.854} & \multirow{2}{*}{0.736} \\
\hline & KC & 1 & 0.738 & & & \\
\hline \multirow{4}{*}{$\begin{array}{l}\text { Leader-Member } \\
\text { Exchange }\end{array}$} & PR & 3 & $0.688-0.806$ & \multirow{4}{*}{$\% 78.52$} & \multirow{4}{*}{0.874} & \multirow{4}{*}{0.830} \\
\hline & $\mathrm{CO}$ & 3 & $0.579-0.894$ & & & \\
\hline & LO & 3 & $0.804-0.888$ & & & \\
\hline & AF & 2 & $0.804-0.839$ & & & \\
\hline \multicolumn{7}{|c|}{ White-Collar Workers } \\
\hline \multirow{4}{*}{$\begin{array}{l}\text { Transformational } \\
\text { Leadership }\end{array}$} & II & 8 & $0.600-0.828$ & \multirow{4}{*}{$\% 76.36$} & & \\
\hline & IC & 3 & $0.663-0.682$ & & & \\
\hline & IM & 4 & $0.663-0.828$ & & 0.945 & 0.924 \\
\hline & IS & 4 & $0.792-0.828$ & & & \\
\hline Knowledge- & KD & 3 & $0.815-0.867$ & & & \\
\hline Sharing Processes & KC & 2 & $0.873-0.926$ & $\% 78.92$ & 0.798 & 0.724 \\
\hline & PR & 3 & $0.802-0.884$ & & & \\
\hline Leader-Member & $\mathrm{CO}$ & 3 & $0.743-0.790$ & $0 / 8750$ & 0926 & 0870 \\
\hline Exchange & LO & 3 & $0.813-0.892$ & $\% 82.50$ & 0.926 & 0.870 \\
\hline & AF & 3 & $0.773-0.874$ & & & \\
\hline
\end{tabular}

Note: Idealized influence (II), Individualized consideration (IC), Inspirational motivation (IM), Intellectual stimulation (IS), Knowledge donating (KD), Knowledge collecting (KC), Professional respect (PR), Contribution (CO), Loyalty (LO), Affect (AF).

The appropriate index values obtained according to the confirmatory factor analysis (CFA) results of the models developed within the framework of transformational leadership, knowledgesharing processes, and leader-member exchange scales are given in Table 2.

Table 2. Fit Indices for CFA

\begin{tabular}{|c|c|c|c|c|c|c|c|c|c|}
\hline & \multicolumn{3}{|c|}{ General Model } & \multicolumn{3}{c|}{ Blue-Collar Workers } & \multicolumn{3}{c|}{ White-Collar Workers } \\
\hline & TL & LXM & KSP & TL & LXM & KSP & TL & LXM & KSP \\
\hline $\mathbf{( X 2} / \mathbf{s d})$ & 2.693 & 2.391 & 1.746 & 2.426 & 2.945 & 2.193 & 1.708 & 1.617 & 1.347 \\
\hline NFI & 0.911 & 0.954 & 0.990 & 0.875 & 0.886 & 0.988 & 0.901 & 0.949 & 0.984 \\
\hline CFI & 0.942 & 0.973 & 0.996 & 0.921 & 0.920 & 0.994 & 0.956 & 0.980 & 0.996 \\
\hline RMSEA & 0.071 & 0.064 & 0.047 & 0.092 & 0.098 & 0.084 & 0.065 & 0.060 & 0.045 \\
\hline
\end{tabular}


As a result of the confirmatory factor analysis, it is observed that although some of the goodness of fit values for the scales are low, they are in the acceptable range of fit values. In addition, as a result of the confirmatory factor analysis, it is seen that the $p$ values reflecting the significance values are $p<0.01$ and all $t$ values exceed 2.56. These results reveal that the scales are statistically significant (Çokluk et al., 2016, pp. 303-304).

The mean, standard deviation, and correlation values of the scales for each model were calculated with the correlation analysis. These values are given in detail in Table 3.

Table 3. Means, Standard Deviation, and Correlation Values of each Model

\begin{tabular}{|l|l|c|c|c|c|c|c|c|c|c|c|c|c|}
\hline & & \multicolumn{4}{|c|}{ General Model } & \multicolumn{3}{c|}{ Blue-Collar Workers } & \multicolumn{3}{c|}{ White-Collar Workers } \\
\hline & Variables & Mean & SD & $\mathbf{1}$ & $\mathbf{2}$ & Mean & SD & $\mathbf{1}$ & $\mathbf{2}$ & Mean & SD & $\mathbf{1}$ & $\mathbf{2}$ \\
\hline $\mathbf{1}$ & TL & 3.939 & 0.57 & 1 & & 3.997 & 0.51 & 1 & & 3.874 & 0.64 & 1 & \\
\hline $\mathbf{2}$ & LXM & 3.997 & 0.66 & 0.75 & 1 & 4.132 & 0.53 & 0.74 & 1 & 3.862 & 0.68 & 0.76 & 1 \\
\hline $\mathbf{3}$ & KSP & 4.026 & 0.58 & 0.54 & 0.54 & 4.068 & 0.48 & 0.57 & 0.58 & 3.997 & 0.59 & 0.57 & 0.58 \\
\hline
\end{tabular}

**Significant at $\mathrm{p}<0.01$

According to the findings in Table 3, it is observed that the averages of the scales are high and there is a positive significant relationship between each variable. It has been determined that there is a moderate positive relationship between the dependent variable knowledge-sharing processes and transformational leadership, and leader-member exchange.

\section{Testing the Research Model and Hypotheses}

According to the results of the analysis, since there is no structural invariance in the models belonging to blue and white-collar workers, each of them was considered as a separate model and comparison analyzes were performed.

Table 4. The Goodness of Fit Values Regarding the Structural Model of Blue and White-Collar Workers

\begin{tabular}{|l|l|c|c|c|c|c|c|}
\hline & & $\mathbf{( X} / \mathbf{s d})$ & NFI & CFI & RMSEA & GFI & RMR \\
\hline Model 1 & General Model & 2.059 & 0.949 & 0.973 & 0.056 & 0.959 & 0.018 \\
\hline Model 2 & Blue-Collar Workers & 2.796 & 0.871 & 0.912 & 0.098 & 0.906 & 0.027 \\
\hline Mode1 3 & White-Collar Workers & 1.462 & 0.937 & 0.979 & 0.052 & 0.943 & 0.024 \\
\hline
\end{tabular}

According to Table 4, it is comprehended that the fit index values of the models are in the acceptable range.

After the relationship determined between variables with correlation analysis, the strength and direction of the impact of the transformational leadership on knowledge-sharing processes and leader-member exchange and the strength and direction of the impact of the leader-member exchange on the knowledge-sharing processes were measured with the path analysis. In addition, a path analysis was made to identify the mediating role of the leader-member exchange in the relationship between transformational leadership and knowledge-sharing processes and ultimately a structural equation modeling was created. The analysis results are given in Table 5 in detail.

Table 5. Path Coefficients for the General Model, Blue and White-Collar Workers Model

\begin{tabular}{|c|c|c|c|c|c|c|c|c|c|c|c|}
\hline \multicolumn{2}{|c|}{} & \multicolumn{4}{|c|}{ General Model } & \multicolumn{3}{c|}{ Blue-Collar Workers } & \multicolumn{3}{c|}{ White-Collar Workers } \\
\hline \multicolumn{2}{|c|}{ Hypotheses } & $\boldsymbol{\beta}$ & $\boldsymbol{t}$ & $\boldsymbol{p}$ & $\boldsymbol{\beta}$ & $\boldsymbol{t}$ & $\boldsymbol{p}$ & $\boldsymbol{\beta}$ & $\boldsymbol{t}$ & $\boldsymbol{p}$ \\
\hline $\mathrm{H}_{1}$ & a & TL ---> LXM & 0.905 & 10.870 & 0.000 & 0.884 & 7.214 & 0.000 & 0.909 & 8.067 & 0.000 \\
\hline $\mathrm{H}_{2}$ & b & LXM ---> KSP & 0.525 & 2.070 & 0.038 & -0.099 & -0.333 & 0.739 & 0.854 & 2.275 & 0.023 \\
\hline
\end{tabular}




\begin{tabular}{|c|c|l|c|c|c|c|c|c|c|c|c|}
\hline $\mathrm{H}_{3}$ & $\mathrm{C}$ & TL ---> KSP & 0.775 & 8.052 & 0.000 & 0.776 & 6.360 & 0.000 & 0.714 & 6.135 & 0.000 \\
\hline $\mathrm{H}_{4}$ & $\mathrm{C}^{\prime}$ & $\begin{array}{l}\text { TL --> LXM -- } \\
->\mathrm{KSP}\end{array}$ & 0.296 & 2.195 & 0.028 & 0.848 & 2.639 & 0.008 & -0.065 & -0.185 & 0.853 \\
\hline \multicolumn{8}{|c|}{ Indirect effect and significance using Sobel test } \\
\hline \\
\hline
\end{tabular}

According to the path analysis results; in the general model, transformational leadership has a positive and significant effect on leader-member exchange $(\beta=0.905, t=10.870, p<0.001)$, leadermember exchange has a positive and significant effect on knowledge-sharing processes $(\beta=0.525, \mathrm{t}$ $=2.070, \mathrm{p}=0.03)$, transformational leadership has a positive and significant effect on knowledgesharing processes $(\beta=0.775, t=8.052, p<0.001)$. According to the results; $\mathrm{H}_{1}, \mathrm{H}_{2}$ and $\mathrm{H}_{3}$ hypotheses are accepted.

In the model of blue-collar workers, transformational leadership has a positive and significant effect on leader-member exchange $(\beta=0.884, t=7.214, p<0.001)$, leader-member exchange has not a positive and significant effect on knowledge-sharing processes $(\beta=-0.099, \mathrm{t}=-0.333, \mathrm{p}=0.739)$, transformational leadership has a positive and significant effect on knowledge-sharing processes $(\beta$ $=0.776, \mathrm{t}=6.360, \mathrm{p}<0.001$ ). According to the results; $\mathrm{H}_{1 \mathrm{a}}$ and $\mathrm{H}_{3 \mathrm{a}}$ hypotheses are accepted, and $\mathrm{H}_{2 \mathrm{a}}$ hypotheses are rejected. In addition, this result indicates that the leader-member interaction has no mediating effect for the model of blue-collar worker, and the $\mathrm{H}_{4 a}$ hypothesis was rejected.

In the model of white-collar workers, transformational leadership has a positive and significant effect on leader-member exchange $(\beta=0.909, \mathrm{t}=8.067, \mathrm{p}<0.001)$, leader-member exchange has a positive and significant effect on knowledge-sharing processes $(\beta=0.854, \mathrm{t}=2.275, \mathrm{p}<0.05)$, transformational leadership has a positive and significant effect on knowledge-sharing processes $(\beta$ $=0.714, \mathrm{t}=6.135, \mathrm{p}<0.001)$. The value of $\mathrm{t}$ values for regression paths are over 1.96 at the $\mathrm{p}<0.05$ significance level or over 2.56 at the $p<0.01$ significance level and $\beta$ values are positive, it indicates that there is a positive significant relationship between the variables (Çokluk et al., 2016, pp. 303304). According to the results obtained; $\mathrm{H}_{1 \mathrm{~b}}, \mathrm{H}_{2 \mathrm{~b}}$ and $\mathrm{H}_{3 \mathrm{~b}}$ hypotheses are accepted.

Regression analysis, developed by Baron \& Kenny (1986), consisting of three stages was used together to measure the mediating effect of leader-member exchange. In the first stage, the effect of transformational leadership on knowledge-sharing processes was analyzed. This effect is for the general model (c) $\beta=0.775 ; \mathrm{R} 2=0.601(\mathrm{p}<0.01)$, and for the model of white-collar workers $(\mathrm{c}) \beta=$ $0.714 ; \mathrm{R} 2=0.510(\mathrm{p}<0.01)$. In the second stage, the effect of transformational leadership on leadermember exchange was analyzed. This effect is for the general model (a) $\beta=0.905$ ( $p<0.01$ ), and for the model of white-collar workers (a) $\beta=0.909$ ( $p<0.01$ ). In the third step, the effect of the leadermember exchange on knowledge-sharing processes was analyzed. This effect is for the general model (b) $\beta=0.525$ ( $p<0.01$ ), and for the model of white-collar workers $(b) \beta=0.854(p<0.05)$. According to the results, it was determined that there is a positive and significant relationship between variables. As a result of including a leader-member exchange in a relationship where transformational leadership affects knowledge-sharing processes, the effect of transformational leadership on knowledge-sharing processes is obtained a significant value $\left(c^{\prime}\right)=0.296$; $R 2=0.645$ ( $p$ $=0.038)$ in the general model, for the model of white-collar workers it is obtained statistically insignificant value $\left(c^{\prime}\right) \beta=-0.065 ; R 2=0.633(p=0.853)$. This result indicates that in the relationship between transformational leadership and the knowledge sharing process, the leader-member exchange has a partial mediating role in the general model and a full mediating role in the model of white-collar workers. The Sobel test was conducted using the MedGraph-I program developed by Jose (2013), to determine whether the mediating effect of leader-member exchange was significant. 
According to the results, it is concluded that the partial mediating effect of leader-member exchange is significant in the general model $(\mathrm{z}=2.042, \mathrm{p}<0.05)$ and the full mediating effect of leader-member exchange is significant in the model of white-collar workers $(z=2.263, p<0.05)$. Also, it was determined that the indirect effect of transformational leadership in the general model is $(a b)=0.475$, and in the model of white-collar workers $(\mathrm{ab}) \beta=0.776$. According to this result, $\mathrm{H}_{4}$ and $\mathrm{H}_{4 b}$ hypothesis was accepted.

\section{Discussion and Conclusion}

Today, the nature of competition depends largely upon successful management of knowledge, because knowledge is the most important value nowadays both for individuals, business and countries. Effective sharing of knowledge among the employees and within the organization affects the success of knowledge management to a great extent. Therefore, academicians, researchers, etc. focus on knowledge management process and make intense researches in this regard. After noticing that the success of knowledge management depends upon the employees rather than the technology or the systems, the researchers have started to focus intensely on knowledge sharing among employees. The studies made on this subject mainly search for means of facilitating knowledge exchange among the employees.

Effective forms of leadership influence behaviors of the employees in a positive manner and make them exhibit behaviors beyond the roles. On the contrary case, the leader displays destructive behaviors, pesters the employees about the work and even prevents them to do their jobs (Sezici, 2016: 107). In this context, leadership behaviors are the most important elements determining the performance and behaviors of the employees. In the researches made within the literature, it has been put forward that constructive leadership forms are leading for knowledge sharing among the employees (Bavik et al., 2017; Bryant, 2003; Sharifkhani et al., 2016; Srivastava et al., 2006).

As a result of the research, the transformational leader displaying motivating behaviors for increasing the performances of the employees has a significant effect on knowledge sharing behaviors of the employees in a positive manner. When such result has been handled in terms of blue and white collar employees, it has been concluded that the transformational leadership behavior encourages knowledge sharing relatively more in blue collar employees than the others. It is observed that the behaviors displayed by transformational leadership, which is accepted as a modern management approach, constitute a management approach meeting the expectations of employees at every level under current conditions. It is demonstrated that such a form of leadership can effectively trigger the employees in line with the benefits of the organization. Such conclusions obtained in the research show similarity to the results of certain studies proving that the transformational leadership affects knowledge sharing of the employees in general terms (Le \& Lei, 2017; Phong \& Son, 2020).

Transformational leaders, taking personal expectations and needs of the employees into account, increase motivation of their employees by exhibiting individualized consideration behavior, and enable realization of high quality leader-member exchange within the framework of respect, loyalty and obligation between the leader and the employees. In other words, it has been concluded that transformational leadership behaviors are effective in improving high quality leadermember exchange. When handled in terms of blue and white collar employees, it has been concluded that transformational leadership behaviors stimulate leader-member exchange relatively more in white collar employees than the others. It is observed that the transformational leader strengthens the individualized mutual relations between the employee and the leader, and as a 
result, leads to leader-member exchange at high level. Such a situation leads to increase in employees' sense of loyalty and makes the employees exhibit much more effort for the success of the leader and the organization. Such results obtained from the research indicate similarity to the results of certain studies proving that the transformational leadership affects leader-member exchange in general terms (Abdalla et al., 2018; Lee, 2005).

Leader-member exchange, referring to the social interaction or exchange between the leader and the employees, has a positively significant effect on knowledge sharing based on knowledge acquisition processes. When such result has been handled in terms of blue and white collar employees, it has been concluded that leader-member exchange affects knowledge sharing to a great extend but there is no such effect when blue collar employees are considered. In case of realization of high quality exchange between the leader and the employee, effective communication networks and an environment of trust are established, and transfer and share of knowledge among individuals become possible. Such conclusion shows similarity to the studies in the literature (Hao et al., 2019; Kim et al., 2017).

It has been concluded that the leader-member exchange, considered as a relational form of leadership, has a partial effect of mediation between transformational leadership and knowledge sharing behaviors of the employees. According to such conclusion, exhibition of supportive and motivating behaviors by the leaders for the success of organizational success is not solely enough for the employees to share knowledge. The effect of transformational leadership on knowledge sharing behaviors of the employees is realized over the high level of trust between the leader and the employee and the quality of the exchange based on performance and award. In other words, the effect of transformational leadership on knowledge sharing behavior changes depending upon the quality of the leader-member exchange. When such result obtained empirically has been handled in terms of blue and white collar employees, it has been concluded that leader-member exchange has a full effect of mediation between the transformational leadership and knowledge sharing of the employees in terms of white collar employees; on the other hand, leader-member exchange has no mediating effect between related variables in terms of blue collar employees. It is seen that the effect of transformational leadership on knowledge sharing realizes by means of the social exchange between the leader and the employee. Moreover, it is understood that effect of transformational leaders on knowledge sharing behaviors of the employees can be realized by more powerful mutual social ties.

The results of this study demonstrate that the leader can motivate the employees more by establishing individualized relations with either blue or white-collar employees, and encourage them to exhibit extra-role behaviors such as knowledge sharing. In the textile sector, if the leaders form high-quality exchanges with the employees, the employees put every kind of opinion and idea forward more freely for the success of the company. Moreover, transformational leadership and leader-member exchange play an important role in the process of having skilled labor force and developing long-term relations with the employees. In this context, it can be said that transformational leadership and leader-member exchange has a significant place in textile sector in order to compete with high labor force turnover rate. Especially in sectors like textile, the leaders can make the employees realize the importance of their jobs, believe that they can do their best, learn new things and share their knowledge with the others, thanks to strong relations to be established with their employees.

One of the most important differences of this study from the other studies made within the literature is the fact this study puts forward that the leader-member exchange acts as a mediator in 
the relation between transformational leadership and knowledge sharing of employees. In other words, it demonstrates that transformational leadership is not solely enough for the exhibition of knowledge sharing behaviors by the employees. The effect of transformational leadership on knowledge sharing behaviors of the employees is realized over the leader-member exchange. Another difference of this study is that all hypotheses have been handled comparatively in terms of blue and white-collar employees. It is thought that this study makes a significant contribution to the literature due to such differences.

As in many kinds of research, this research has its limitations too. Due to limitedness of current opportunities in terms of cost and time, the research has been carried out with limited sample size and convenience sampling method. Furthermore; even though obtained results support formation of an opinion to make deduction, one should be careful at the point of generalizing because the measurement of the variables included in the study depends upon personal statements and perceptions. It is recommended that studies should be made at a larger scale and in different sectors in order to make the results more significant and understandable. Moreover; it is suggested that the researches, related to evaluating behavioral tendencies of the employees, should be taken into account and contain the dimensions of culture.

\section{References}

Abdalla, M., Shawky, A., Ragab, A. \& Gouda, H. (2018). Transformational leadership role in creating an effective work-related context including; Leader-member exchange, Followers' participation in decision-making process, and followers' resistance to change for successful performance. The Business and Management Review, 9(4), 95-106.

Baron, R.M. \& Kenny, D.A. (1986). The Moderator-mediator variable distinction in social psychological research: conceptual, strategic, and statistical considerations. Journal of Personality and Social Psychology, 51(6), 1173-2001.

Bartol, K. \& Srivastava, A. (2002). Encouraging knowledge sharing: The role of organizational rewards. Journal of Leadership and Organisation Studies, 9(1), 64-76.

Bass, B. M. (1985). Leadership and performance beyond expectations. New York, NY: Free Press.

Bass, B.M. \& Avolio, B.J. (1994), Improving organizational effectiveness through transformational leadership. Thousand Oaks, CA: Sage Publications.

Bass, B.M. \& Avolio, B.J. (1997). Full range leadership development: Manual for the multifactor leadership questionnaire. Redwood City, CA: Mind Garden.

Bavik, Y. L., Tang: M., Shao, R. \& Lam, L. M. (2018). Ethical leadership and employee knowledge sharing: Exploring dual-mediation paths. The Leadership Quarterly, 29(2): 322-332.

Birasnav, M., Rangnekar, S. \& Dalpati, A. (2011). Transformational leadership and human capital benefits: The role of knowledge management. Leadership and Organization Development Journal, 32(2), 106-126.

Bryant, S. E. (2003). The role of transformational and transactional leadership in creating, sharing and exploiting organizational knowledge. Journal of Leadership \& Organizational Studies, 9, 32-44.

Carmeli, A., Atwater, L. \& Levi, A. (2011). How leadership enhances employees' knowledge sharing: the intervening roles of relational and organizational identification. The Journal of Technology Transfer, 36(3), 257-274.

Cengiarslan, Fatih (2020). Tekstil sektörü istihdam deposu oldu. [https://www.textilegence.com/adaso-tekstil-sektoru-istihdam-deposu-oldu/], Date of Access: 18.12.2020.

Choi, S.B., Kim, K., Ullah, S.M.E. \& Kang, S.-W. (2016). How transformational leadership facilitates innovative behavior of Korean workers: Examining mediating and moderating processes. Personnel Review, 45(3), 459-479.

Chowdhury, S. (2005). The role of affect and cognition based trust in complex knowledge sharing. Journal of Managerial Issues, 17(3), 310-326. 
Çokluk, Ö., Şekercioğlu, G. \& Büyüköztürk, Ş. (2016). Sosyal Bilimler İçin Çok Değişkenli İstatistik SPSS ve LISREL Uygulamaları, (4. Bask1), Ankara: Pegem Akademi Yayınları.

Dansereau, F., Graen, G. \& Haga, W.J. (1975). A vertical dyad linkage approach to leadership within formal organizations: a longitudinal investigation of the role making process. Organizational Behavior and Human Performance, 13(1), 46-78.

Davenport, T. \& Prusak, L. (1998). Working knowledge: How organizations manage what they know, Boston: Harvard Business School Press.

Deluga, R. J, (1992). The relationship of leader-member exchanges with laissez-faire, transactional, and transformational leadership. in impact of leadership (Eds. K. E. Clark, M. B. Clark, \& D. R. Campbell, (pp. 237-247). Greensboro, NC: Center for Creative Leadership.

Du, R., Ai, S. \& Ren, Y. (2007). Relationship between knowledge sharing and performance: A survey in Xi'an, China. Expert systems with Applications, 32(1), 38-46.

Düger, Y. S. (2020a). Investigation of contemporary leadership styles within the framework of social exchange theory. in Interdisciplinary Public Finance, Business and Economics Studies Volume III, (Ed. A. Akınc1), (pp. 315-324), Berlin: Peter Lang GmbH.

Düger, Y. S. (2020b). The Effect of leader-member exchange (LMX) on employee voice and turnover intention: the moderator role of psychological empowerment. Gaziantep University Journal of Social Sciences, 19(3), 1215-1236.

Fitzgerald, S. \& Schutte, N.S. (2010). Increasing transformational leadership through enhancing selfefficacy. Journal of Management Development, 29(5), 495-505.

Fong, C. Y., Ooi, K. B., Tan, B. I., Lee, V. H. \& Chong, A. Y. L. (2011). HRM practices and knowledge sharing: An empirical study. International Journal of Manpower, 32 (5/6), 704-723.

Gagne, M. (2009). A model of knowledge-sharing motivation. Human Resource Management, 48(4): 571-589.

Graen, G. B. \& Uhl-Bien, M. (1995). Relationship-based approach to leadership: Development of leader-member exchange (LMX) theory of leadership over 25 years: Applying a multi-level multi-domain perspective. Leadership Quarterly, 6(2), 219-247.

Graen, G., Novak. M. A., \& Sommerkamp: (1982). The effects of leader-member exchange and job design on productivity and job satisfaction: Testing a dual attachment model. Organizational Behavior and Human Performance, 30, 109-131.

Graen, G.B. \& Uhl-Bien, M. (1991). The transformation of professionals into self-managing and partially self-designing contributors: Towards a theory of leadership making. Journal of Management Systems, 3(3), 33-48.

Gürçay, G. (2015). Examination of the mediating role of leader-member exchange on the association between transformational leadership and innovative behavior: a study in Turkish technological organizations. World Academy of Science, Engineering and Technology International Journal of Economics and Management Engineering, 9(12), 4293-4297.

Han, S.H., Seo, G., Yoon, S.W. \& Yoon, D.-Y. (2016). Transformational leadership and knowledge sharing: Mediating roles of employee's empowerment, commitment, and citizenship behaviors. Journal of Workplace Learning, 28(3), 130-149.

Hao, Q., Shi, Y. \& Yang, W. (2019). How leader-member exchange affects knowledge sharing behavior: understanding the effects of commitment and employee characteristics. Frontiers in Psychology, 10(2768), 1-13.

Howell, J. M. \& Avolio, B. J. (1993). Transformational leadership, transactional leadership, locus of control, and support for innovation: key predictors of consolidated-business-unit performance. Journal of Applied Psychology, 78(6), 891-902.

Ipe, M. (2003). Knowledge sharing in organizations: A conceptual framework. HRM Development Review, 2, 337-359.

Istanbul Textile and Apparel Exporters' Association (2019), Toplam tekstil ve hammaddeleri sektörü 2019 yılı aralk ihracatı performans raporu. [https://www.itkib.org.tr/Home/KbDownload/tekstil-Ihracat-degerlendirme-notu-aralik2019], Date of Access: 18.12.2020. 
Jose: E. (2013). MedGraph-I: A programme to graphically depict mediation among three variables: the internet version, version 3.0. Victoria University of Wellington, Wellington, New Zealand. [https://psychology.victoria.ac.nz/medgraph], Date of Access: 20.12.2020.

Kalaycı, Ş. (2016). SPSS uygulamalı çok değişkenli istatistik teknikleri. Ankara: Asil Yayınları,

Kim, S. L., Han, S., Son, S. Y., \& Yun, S. (2017). Exchange ideology in supervisor subordinate dyads, LMX, and knowledge sharing: a social exchange perspective. Asia Pacific Journal of Management, 34, 147-172.

Krishnan, V. R. (2005). Leader-member exchange, transformational leadership, and value system. Electronic Journal of Business Ethics and Organization Studies, 10(1), 14-21.

Kuhnert, K. W. \& Lewis: (1987). Transactional and transformational leadership: A constructive/ developmental analysis. The Academy of Management Review, 12(4), 648-657.

Le, P. B. \& Lei, H. (2019). Determinants of innovation capability: the roles of transformational leadership, knowledge sharing and perceived organizational support. Journal of Knowledge Management, 23(3), 527-547.

Le, P. B. \& Lei, H. (2017). How transformational leadership supports knowledge sharing: Evidence from Chinese manufacturing and service firms. Chinese Management Studies, 11(3), 479-497.

Lee, J. \& Wei, F. (2008). Uncover the black-box of leadership effectiveness: Leader-member exchange as the mediator. Frontiers of Business Research in China, 2(2), 240-255.

Lee, J. (2005). Effects of leadership and leader-member exchange on commitment. Leadership $\mathcal{E}$ Organization Development Journal, 26(8), 655-672.

Li, G., Shang, Y., Liu, H. \& Xi, Y. (2014). Differentiated transformational leadership and knowledge sharing: A cross-level investigation. European Management Journal, 32(4), 554-563.

Liao, S., Fei, W.-C. \& Chen, C.-C. (2007). Knowledge sharing, absorptive capacity, and innovation capability: an empirical study of Taiwan's knowledge-intensive industries. Journal of Information Science, 33(3), 340-359.

Liden, R. \& Maslyn, J. (1998). Multidimensionality of leader member exchange: An empirical assessment through scale development. Journal of Management, 24(1), 43-72.

Lin, C.P. (2007). To share or not to share: Modeling tacit knowledge sharing, its mediators and antecedents. Journal of Business Ethics, 70(4), 411-428.

Lin, H.-F. \& Lee, G.G. (2004). Perceptions of senior managers toward knowledge-sharing behavior. Management Decision, 42(1), 108-125.

Lin, H.-F. (2007). Knowledge sharing and firm innovation capability: An empirical study. International Journal of Manpower, 28(3/4): 315-332.

Macit, M. (2003). Leadership and Bass transactional and transformational leadership theory. Selçuk Üniversitesi İktisadi ve İdari Bilimler Fakültesi Sosyal ve Ekonomik Araştırmalar Dergisi, 1(5), 87-114.

Mohammadi, A. \& Boroumand, Z. (2016). Transformational leadership and knowledge sharing. International Journal of Information Science and Management, 14(2), 83-96.

$\mathrm{Ng}, \mathrm{T}$. W. G. (2017). Transformational leadership and performance outcomes: Analyses of multiple mediation pathways. The Leadership Quarterly, 28(3), 385-417.

Nonaka, I. (1994). A dynamic theory of organizational knowledge creation. Organization Science, 5, 14-37.

Phong, L. B. \& Son, T. T. (2020). The link between transformational leadership and knowledge sharing: mediating role of distributive, procedural and interactional justice. Journal of Information E Knowledge Management, 19(3) 2050020, 1-19.

Phong, L. B., Hui, L. \& Son, T. T. (2018). How leadership and trust in leaders foster employees' behavior toward knowledge sharing. Social Behavior and Personality: An International Journal, 46(5), 705-720.

Sezici, E. (2016). İzleyicilerin yıkıcı liderlik algısı ve sonuçları. Dumlupınar Üniversitesi Sosyal Bilimler Dergisi, 47, 106-121.

Shamir, B., House, R., \& Arthur, M. B. (1993). The motivational effects of charismatic leadership: A self-concept based theory. Organization Science, 4(4), 577-594. 
Sharifkhani, M., Khazaei Pool, J. \& Asian, S. (2016). The impact of leader-member exchange on knowledge sharing and performance: An empirical investigation in the oil and gas industry. Journal of Science and Technology Policy Management, 7(3), 289-305.

Sherony, K.M. \& Green, S.G. (2002). Coworker exchange: relationships between coworkers, leadermember exchange and work attitudes. Journal of Applied Psychology, 87(3), 542-548.

Shusha, A. (2013). The Mediating role of leader-member exchange in the relationship between transformational leadership and job performance. European Journal of Business and Management, 5(8), 157-164.

Srivastava, A., Bartol, K. M. \& Locke, E. A. (2006). Empowering leadership in management teams: Effects on knowledge sharing, efficacy, and performance. Academy of Management Journal, 49(6): 1239-1251.

Su, T., Wang, Z., Lei, X., \& Ye, T. (2013). Interaction between Chinese employees' traditionality and leader-member exchange in relation to knowledge-sharing behaviors. Social Behavior and Personality, 41(7), 1071-1081.

Wang, H., Law, K. S., Hackett, R. D., Wang, D., \& Chen, Z. X. (2005). Leader-member exchange as a mediator of the relationship between transformational leadership and followers' performance and organizational citizenship behavior. Academy of Management Journal, 48, 420-432.

Wang, S., \& Noe, R. A. (2010). Knowledge sharing: a review and directions for future research. Human Resource Management Review, 20(2), 115-131.

Wayne, S. J., Shore, L. M., \& Liden, R. C. (1997). Perceived organizational support and leadermember exchange: A social exchange perspective. Academy of Management Journal, 40, 82-111.

Yang, J. T. (2008). Individual attitudes and organisational knowledge sharing. Tourism Management. 29(2): 345-353.

Yukl, G. (1989). Managerial leadership: A review of theory and research. Journal of Management, 15(2), 251-289. 